\title{
ALTERNATE DATA SOURCES FOR SOIL SURVEYS ON RANGELAND
}

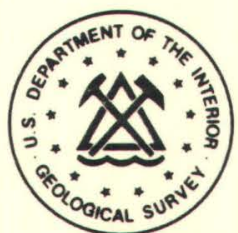

U.S. Geological Survey Open-File Report 83-880 
ALTERNATE DATA SOURCES FOR SOIL SURVEYS ON RANGELAND

U.S. Geological Survey

Open File Report $83-880$ 


\section{ALTERNATE DATA SOURCES}

FOR

SOIL SURVEYS ON

RANGELANDS

By E. H. Horvath, A. A. Klingebiel,

D. G. Moore, and E. A. Fosnight

1983

U.S. Geological Survey Open-File Report 83-880 
Soil information is an essential theme in a digital information base for 1 and management and resource monitoring, but public land management agencies seldom have detailed soil maps available for all of the area under their administration. Most of these agencies conduct soil surveys on a scheduled basis, but escalating costs and declining budgets are reducing the number of surveys that can be scheduled.

Digital elevation and satellite spectral data are available or are obtainable for all areas in the continental United States and may be used as an aid to produce soils data. A study was conducted in the Grass Creek Resource Area in north-central Wyoming to assess the utility of incorporating digital elevation and Landsat data into an information base for soil survey and to evaluate the usefulness of these data as an input to an order-three soil survey.

Slope-interval maps were produced from digital elevation data and topographic maps of three 7.5-minute quadrangle areas. These slope-interval maps were then overlaid on orthophotoquadrangles and used to produce photo-interpreted physiographic maps. These physiographic maps were digitized into a data base and used with Landsat multispectral scanner data to produce tabular summaries that describe each map polygon in terms of physiographic unit, slope, aspect, elevation, area, and spectral values. A good relationship was found between the physiographic units and soil mapping units

1/ Technicolor Government Services, Inc., Sioux Falls, SD 57198. Work performed under U.S. Geological Survey contract no. 14-08-0001-20129.

2/ Soils consultant, SALUT Inc., Columbia, MD 21044. Work performed under U.S. Soil Conservation Service order no. 0065-SCS-82.

3/ Chief, Bioscience Applications Section, EROS Data Center, Sioux Falls, SD. 57198 . 
defined during a conventional soil survey, and between the Landsat spectral categories and existing vegetation communities. Field evaluations confirmed the feasibility of using this approach for producing physiographic maps as an aid for mapping soils and range sites. The project is a cooperative investigation of the Earth Resources Observation Systems Data Center of the U.S. Geological Survey, the Soil Conservation Service, and the Bureau of Land Management.

\section{INTRODUCTION}

The need for information about soils when making land management decisions has long been recognized in the United States. Soil surveys are a part of land management plans and have been incorporated into data bases for this purpose since the $1800^{\prime}$ s. Public land management agencies, however, do not always have detailed soil maps for all the land that they administer. They conduct soil surveys on a scheduled basis; however, escalating costs and declining budgets limit the area that can be surveyed.

Various remote sensing techniques and different types of remotely sensed data have been used as tools for soil surveys, effectively reducing the field time required by increasing the efficiency of the survey procedures $(2,4,10)$. of the five soil-forming factors, none is as evident on western U.S. rangelands as topography or relief, thus soil scientists rely heavily on the relationships between soil patterns and physiography during the photo-interpretation process that accompanies a soil survey (5). Slope and aspect are closely associated with soil depth and available moisture, which in turn influence the kind and the amount of plants that will grow on a given site.

Recently, digital information systems that contain information about administrative and political boundaries, vegetation, geology, and soils have been established for much of our public land $(6,7)$. These data are used in the decision-making process, and during this process the soils data frequently are indispensable (3). Geographic information systems have been used to derive land management information; however, the same approach may assist in deriving the basic resources data necessary as information layers by combining two or more layers of data. An example is the use of multispectral Landsat and digital elevation data to derive a map of ecologically significant vegetation communities ( 3 ).

Digital elevation (U.S. GeoData) information is available or obtainable for areas in the continental United States. At a scale of 1:24,000, with a vertical resolution of one meter $(1,11)$ these data meet national map accuracy standards. The data are produced and marketed by the National Cartographic Information Center in Reston, Va. These elevation data may aid in reducing the field time necesary to achieve the goals of a soil survey without compromising the currently accepted standards of accuracy. The objective of this study was to assess the utility of incorporating digital elevation and Landsat spectral data into a digital information base for an order-three soil survey. 
The Grass Creek Resource Area (GCRA) is located in the Bighorn basin in west-central Wyoming and extends from the Bighorn river on the east to the Wood River on the west. Owl Creek is the southern boundary and the Greybul1 River forms the northern boundary. Elevations range from about 1,300 m at Greybull to over $3,000 \mathrm{~m}$ in the Absaroka Mountains in the southwest corner of the resource area. Temperature extremes range from over $40^{\circ} \mathrm{C}$. to record lows of $-45^{\circ} \mathrm{C}$. Mean annual precipitation ranges from 110 to $450 \mathrm{~mm}$, with the most precipitation occurring at the higher elevations.

Three 7.5-minute quadrangles within the GCRA were selected for this project on the basis of differences in landscape, soils, and vegetation (Fig. 1).

Sucker Dam quadrangle is comprised of mostly level topography, with elevations from 1,300 to $1,600 \mathrm{~m}$ and annual precipitation from 112 to $200 \mathrm{~mm}$. The dominant vegetation communities are associations of bluegramma and cactus, sagebrush, Gardner's saltbush, and mixed grasses. Dominant soils are associations of Torrifluvents, Torriorthents, Haplargids, and Natrargids (8).

Gillies Draw quadrangle has level to rolling topography, with elevations that range from 1,600 to 2,000 meters and mean annual precipitation from 225 to $337 \mathrm{~mm}$. The vegetation on this quadrangle is very similar to that of Sucker Dam, but larger areas are dominated by sagebrush communities. The soils are less affected by problems of salinity than those on the Sucker. Dam quadrangle, and the dominant Great Groups in the area being primarily Torriorthents, Haplargids, and Camborthids.

Soapy Dale Peak quadrangle has rolling to steep topography in the north half of the quadrangle, and steep to very steep terrain in the south half. Precipitation averages 360 to $450 \mathrm{~mm}$ annually, and elevations range from $2,200 \mathrm{~m}$ to $3,000 \mathrm{~m}$. Mixed grass communities occur on the non-forested hilltops and valleys, the latter frequently being heavily invaded by sagebrush. Forest communities vary from Juniper and Limber Pine associations to Limber Pine and Ponderosa Pine mixes.

\section{THE DATA BASE}

An existing digital data base for the Grass Creek Resource Area contained information on administrative boundaries, Landsat multispectral data for June 8, 1978, Landsat multispectral data for September 9, 1978, digitized order-three soil survey boundaries, precipitation zone boundaries, vegetation, and range capability classes derived by merging soil and vegetation data $(3,8)$. All data had been geometrically corrected and geographically referenced to a Universal Transverse Mercator projection mapping base.

Digital elevation data (U.S. GeoData) for the three quadrangles were obtained from the National Cartographic Information Center in Reston, Virginia, $(1,11)$. The $1: 24,000$ scale elevation data exist on a 30 -meter grid in the Universal Transverse Mercator projection. These elevation data were used to generate slope maps, effectively adding new information to the data base. The algorithm used to compute slope for each pixel from this data (Fig. 2) used an average value of slope that was calculated as rise over 100 units of run for 


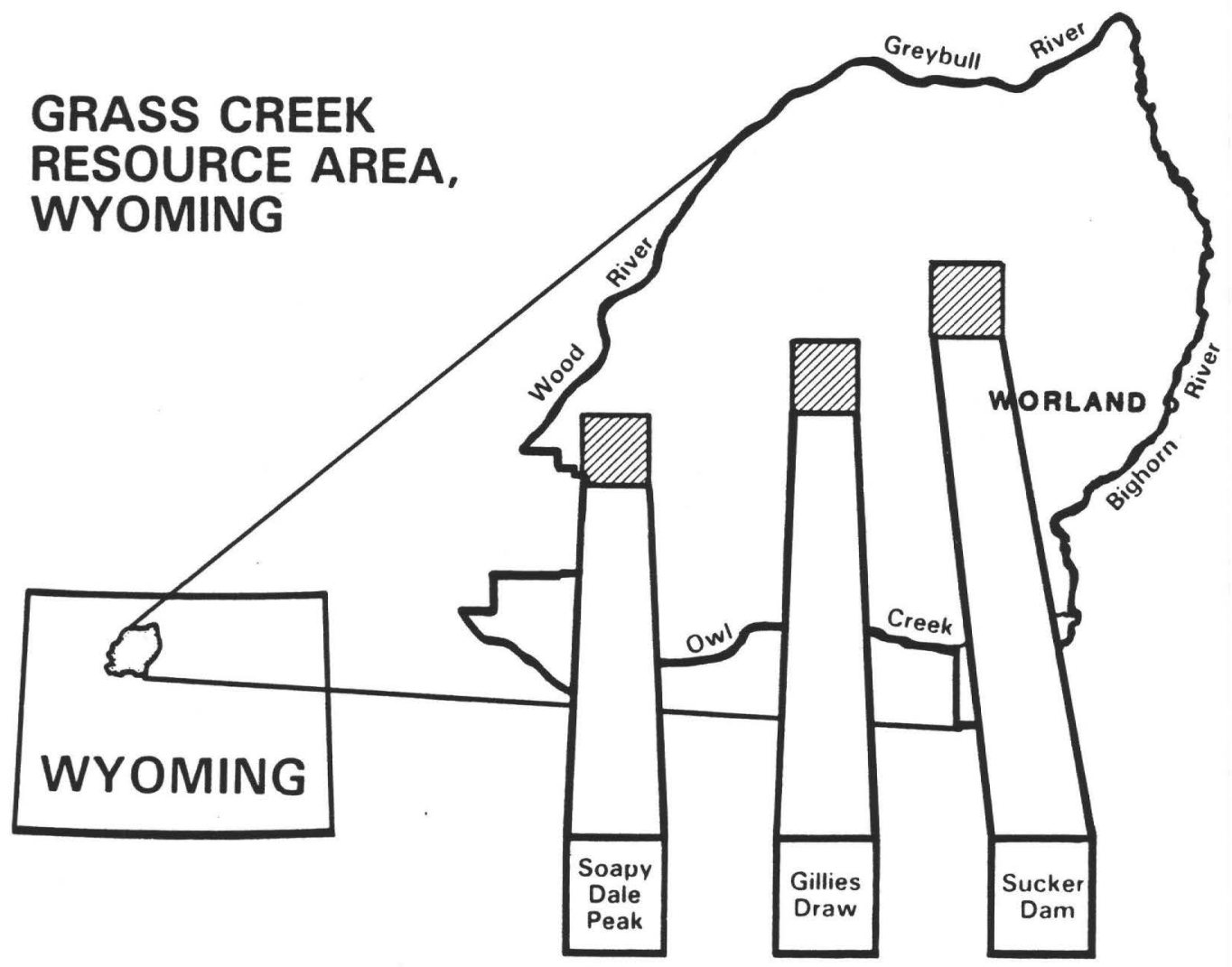

Figure 1.-- Location of the Grass Creek Resource Area and of the three 7.5-minute quadrangle areas that were selected for this study. 


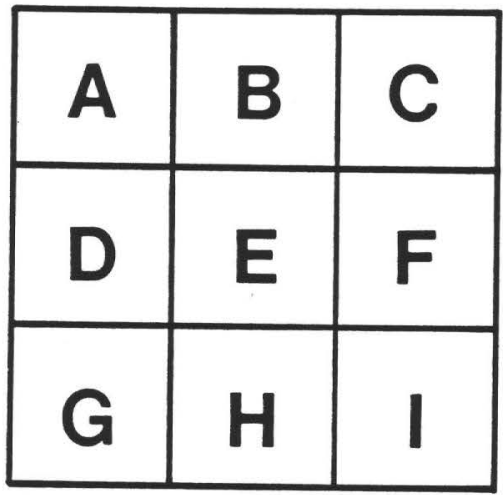

The Slope of $\mathbf{E}=100 \times \sqrt{\sum_{i=1}^{4} \nu^{2}}$

where:

$$
\begin{aligned}
& v_{1}=\frac{A-E}{\overline{A E}}-\frac{1-E}{\overline{I E}} \\
& v_{2}=\frac{B-E}{\overline{B E}}-\frac{H-E}{\overline{H E}} \\
& v_{3}=\frac{C-E}{\overline{C E}}-\frac{G-E}{\overline{G E}} \\
& v_{4}=\frac{F-E}{\overline{F E}}-\frac{D-E}{\overline{D E}}
\end{aligned}
$$

Figure 2.--Computation of slope from digital elevation data, where slope is calculated as percent in units of rise per hundred units of run in eight directions and then averaged for each element. 
eight directions from each 30 -meter grid cell. Using slope breaks that were desirable for soil mapping slope interval maps were produced for each of the three 7.5-minute quadrangles, with consideration for the differences in physiography between the three quadrangles. For example, narrow slope classes were selected for the more gentle terrain in the Sucker Dam quadrangle, and broader categories were chosen for the steeper areas, such as those found in the Soapy Dale Peak quadrangle. Care was taken to avoid using slope classes that would dissect similar types of physiography. Thus, the slope classes selected for Sucker Dam were $0-2,3-7,8-15,16-30$, and greater than $31 \%$; the slope classes selected for the Gillies Draw quadrangle were 0-3, 4-12, 13-25, 26-40, and greater than 40\%; and the slope classes for Soapy Dale Peak were $0-5,6-15,16-40$, and greater than $40 \%$.

To avoid incorporating some unwanted detail in the slope-class maps, a smoothing algorithm to eliminate areas smaller than 10 acres was applied to the images before printing the slope-class maps (9). Figure 3 is an example of a slope-class map for a portion of the Soapy Dale Peak quadrangle.

\section{LANDSAT DATA}

Using the June 8, 1978, Landsat multispectral scanner data for the three quadrangles, a clustering algorithm was used to separate fourteen spectral categories. A maximum-likelihood algorithm was then used on the four-band spectral data to generate spectral maps, wherein areas are depicted that are relatively uniform in terms of the multispectral data (9). The spectral maps were color-coded to identify fourteen spectral classes and printed at a scale of $1: 24,000$. These types of maps have been used successfully to determine the placement of pedon description sites and to help delineate soil-vegetation interactions $(3,4)$. To aid in the interpretation of these spectral maps, a transformation was employed to calculate the relative brightness and greenness of the individual spectral classes. These transformations were of the form:

$$
\begin{aligned}
& \text { Brightness }=(\text { MSS } 4+\text { MSS } 5+\text { MSS6 }) / 3 \text {, and } \\
& \text { Greenness }=(\text { MSS } 6+\text { MSS } 7-\text { MSS5 }) / 2
\end{aligned}
$$

where MSS4, MSS5, MSS6, and MSS7 are the radiance values for the four Landsat multispectral scanner bands. The brightness and greenness values were calculated for the unclassified spectral data and later used in the tabular summaries.

\section{PHYSIOGRAPHIC MAPS}

Orthophotoquads served as the base on which the lines resulting from the subsequent interpretations were drawn. The slope-class maps were plotted on acetate, overlaid on topographic maps and traced, correcting for displacement of polygons that may have occurred during the smoothing. At the same time landforms that may have been related to the different slopes are considered. A portion of this re-traced slope-clas map is shown in figure 4 overlaying a topographic map. This new slope-class overlay was placed on the orthophoto to further interpret the slope-class delineations with respect to surface grey-tones and physiography. The resulting slope-class maps depict polygons within given slope intervals that also delineate certain types of landforms. An example of a finished slope-class map, extracted for an area within the Soapy Dale Peak quadrangle, is illustrated in Figure 5. 


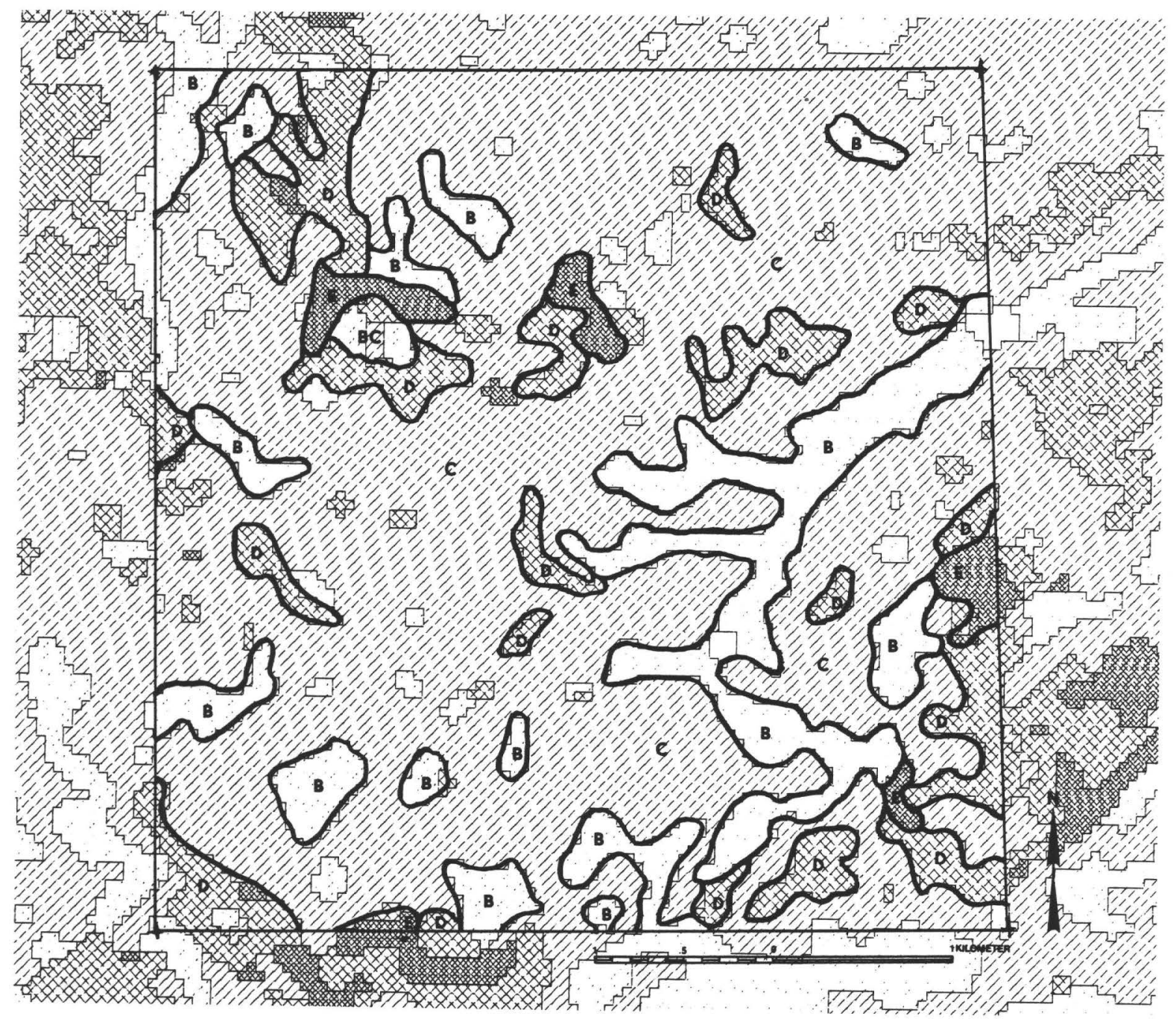

Figure 3.--Example of a plot of a smoothed digital slope-class map of a portion of the Soapy Dale Peak quadrangle where larger polygons have been traced to aid in the interpretation. 


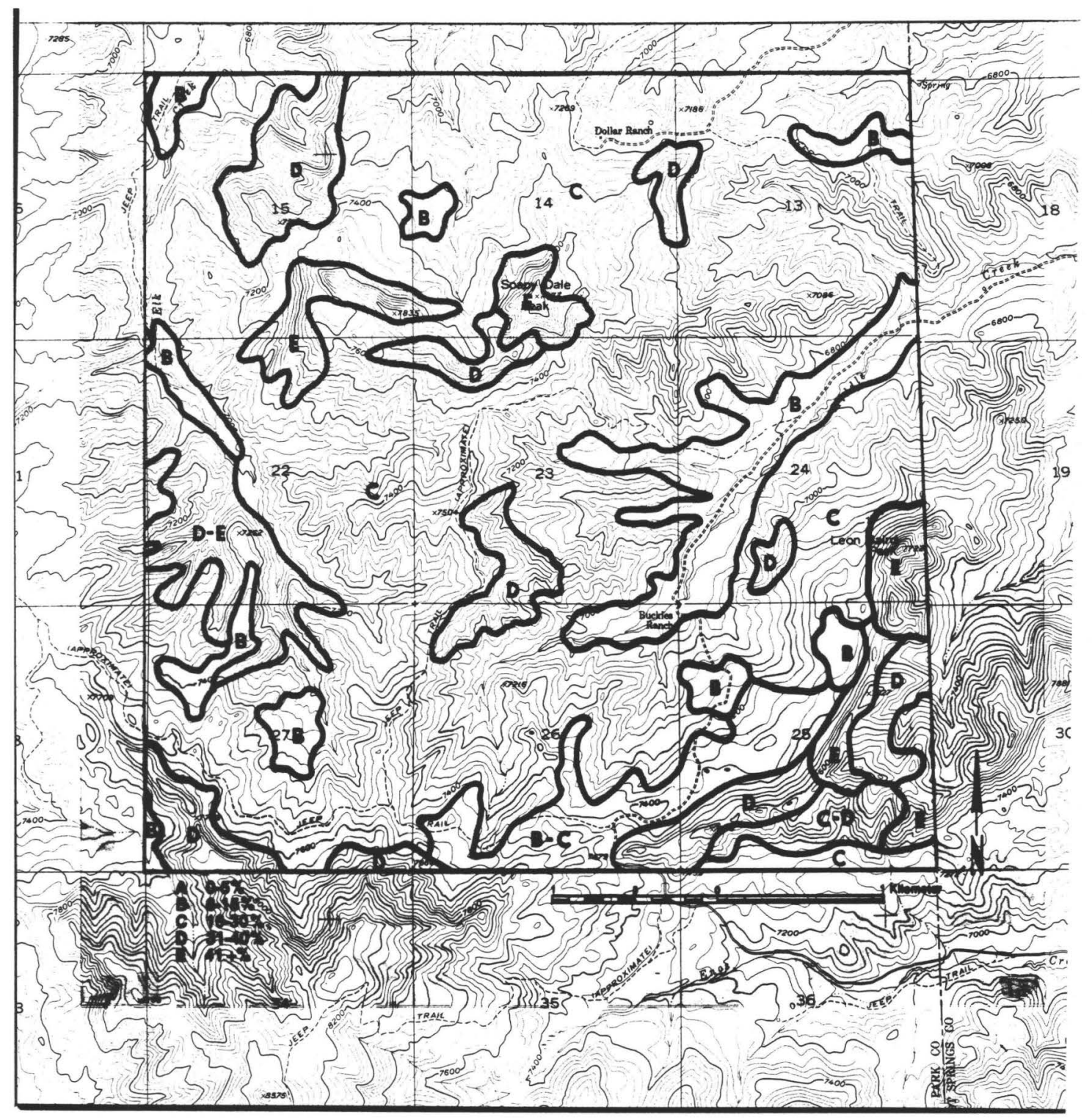

Figure 4.--Example of a slope-class map overlaying a portion of the Soapy Dale Peak topographic map, where the lines of the digital slope class product were adjusted to correct for displacement of polygons that may occur during area filtering. 


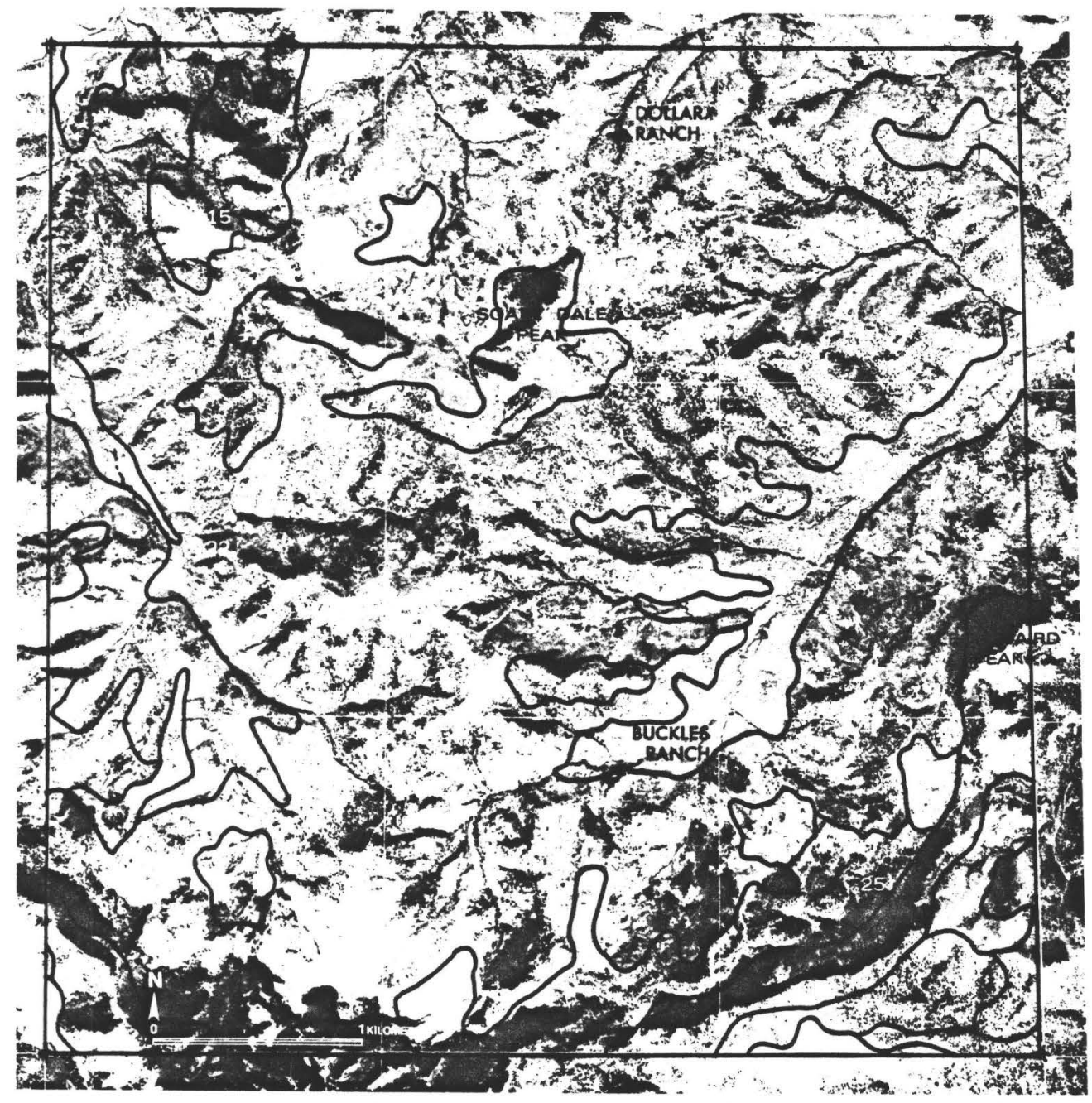

Figure 5.--Example of a finished slope-class map for a portion of the Soapy Dale Peak quadrangle, generated by overlaying a plot of the digital slope-class map on the orthophoto and tracing all units considered important for mapping physiography. 
The revised slope-interval maps were then overlaid on the orthophotos during a photo interpretation process that resulted in physiographic maps. Each mapping unit was labeled according to soil subgroup, parent material, landform, and slope category. The soil subgroup and parent material

information was derived from existing maps of the area, and the slope category

information was derived from the digital slope-class maps. The soil

association and geology maps were consulted during the interpretation.

Table 1 give an example of the tabular result of this interpretation, and an excerpt from a finished physiographic map is presented in Figure 6 .

\section{TABULAR SUMMARIES}

The physiographic maps were digitized and entered into the data base, after which information from other data layers was listed by physiographic unit (Table 2).

On these tabular summaries, several layers of information within the data base are examined with respect to specific delineations. The mapping unit number of the polygon is listed so that it may be cross-referenced to the tabular information resulting from the interpretation (Table 1). Area, mean percent slope, dominant aspect, and mean elevation are listed for each polygon, as are the Landsat data in terms of brightness and greenness transformations and occurrence of various spectral classes. By studying the number of different classes and the number of spectral-class polygons of various dimensions that occur within physiographic unit polygons, clues may be obtained about the relative complexity of the surface patterns within a polygon.

\section{FIELDWORK}

The physiographic maps were used as overlays on the orthophotos and on the fourteen-class spectral maps during the field checking. Twenty sites were selected for each 7.5-minute quadrangle, with the intention of sampling as many different types of physiography and soils as possible. Each site and the surrounding area were located on the physiographic and spectral maps and, once located in the field, evaluated with respect to soils, physiography, vegetation types, and range sites. A helicopter was used as a field vehicle to reach areas that were not readily accessible by car.

\section{RESULTS}

During the fieldwork a good relationship between the physiographic units and soils was found. The spectral maps frequently gave clues to patterns of vegetation types and to soil mapping unit inclusions within physiographic units. The slope categories, derived from the digital elevation data as represented on the physiographic map, were found to be consistently accurate on all three quadrangles with the exception of the nearly level (0-2\%) areas on the Sucker Dam quadrangle. When level areas had been identified on the digital slope map, they were found to be correct; however, many inclusions of leve1 areas occurred within the 3-7\% slope category. On all three quadrangles the spectral classes that occurred within the physiographic units helped identify range sites. This was true where the spectral classes related to soil/vegetation interactions that identified different range sites. Figure 7 is a portion of the Soapy Dale Peak quadrangle where the physiographic map was 
Table 1.--Example of tabular results from image and map interpretation, using slope-class overlays on an orthophoto, for a portion of the Soapy Dale Peak quadrangle.

\begin{tabular}{llcll}
\hline $\begin{array}{l}\text { Physio- } \\
\text { graphic } \\
\text { Unit }\end{array}$ & Soil Subgroup & $\begin{array}{l}\text { Slope } \\
\text { Category } \\
\text { (percent) }\end{array}$ & Parent Material & Landform \\
\hline $209 \mathrm{C}$ & Ustic Torriorthents & $16-40$ & $\begin{array}{l}\text { Residuum from } \\
\text { shale and silt- } \\
\text { stone }\end{array}$ & $\begin{array}{l}\text { Moderately steep } \\
\text { to steep }\end{array}$ \\
$211 \mathrm{~B}$ & Borollic Haplargids & $6-15$ & $\begin{array}{l}\text { Alluvium from } \\
\text { sedimentary } \\
\text { sandstone and } \\
\text { shale }\end{array}$ & $\begin{array}{l}\text { Sloping } \\
\text { alluvial fans and } \\
\text { bottoms }\end{array}$ \\
$222 \mathrm{C}$ & $\begin{array}{l}\text { Argic Pachic and Argic } \\
\text { Lithic Cryoborolls }\end{array}$ & $16-40$ & $\begin{array}{l}\text { Fine-grained } \\
\text { igneous rocks }\end{array}$ & $\begin{array}{l}\text { Moderately steep } \\
\text { to steep } \\
\text { mountain slopes }\end{array}$ \\
& $\begin{array}{l}\text { Argic Pachic } \\
\text { Cryoborolls }\end{array}$ & $16-40$ & $\begin{array}{l}\text { Alluvium from } \\
\text { clay shale }\end{array}$ & $\begin{array}{l}\text { Moderately steep } \\
\text { to steep } \\
\text { mountain slopes }\end{array}$ \\
\hline
\end{tabular}




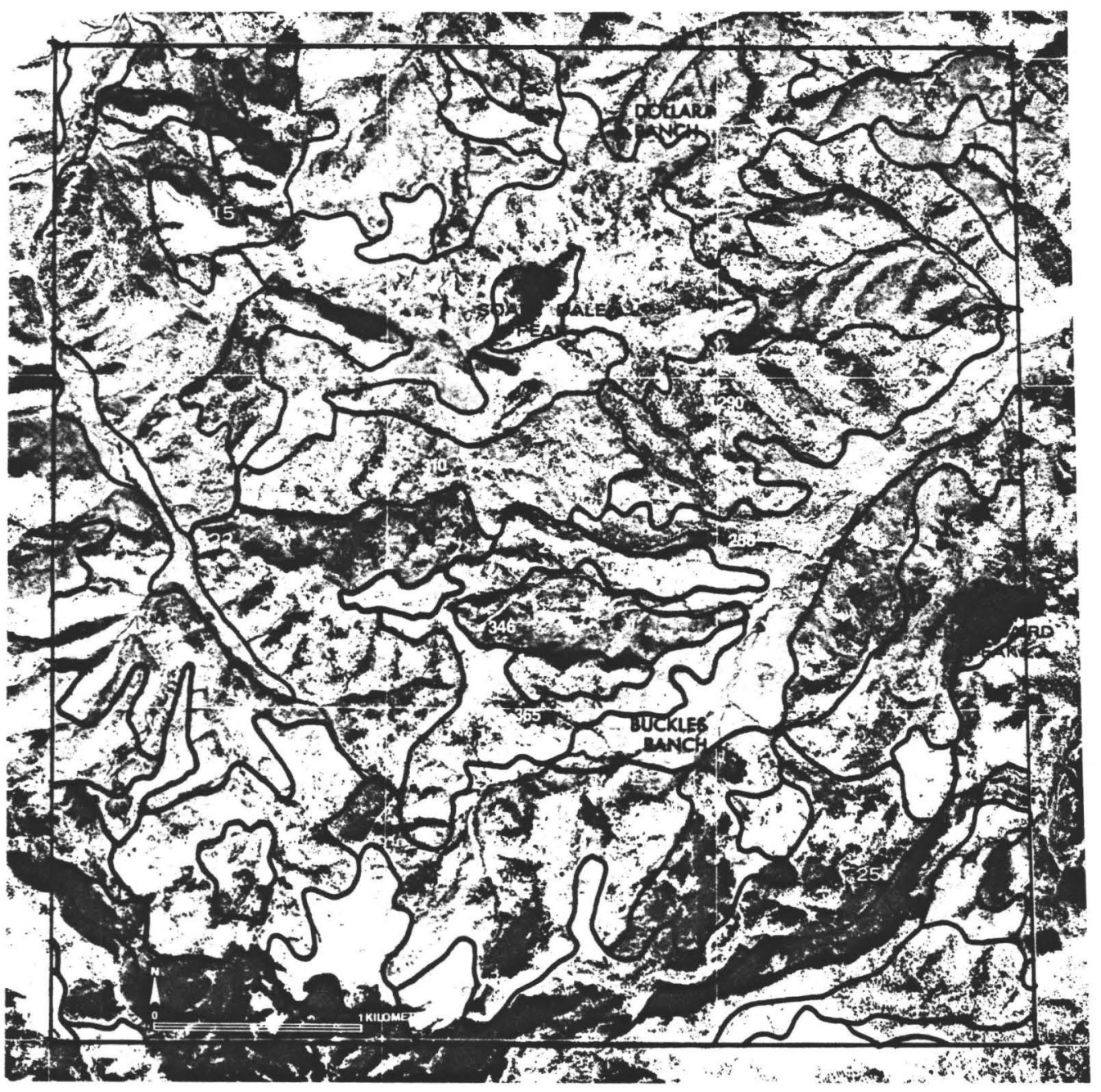

Figure 6.--Portion of a finished physiographic map for the Soapy Dale Peak quadrangle overlaying an orthophoto. The five polygons that have been labeled are described in Table 2. 
Table 2.--Portion of a tabular summary generated for the Soapy Dale peak quadrangle, listing information from the digital data base for the five polygons numbered on the physiographic map in Figure 6.

(SD indicates standard deviation)

\begin{tabular}{|c|c|c|c|c|c|c|c|c|c|c|c|c|c|c|c|c|c|c|}
\hline \multicolumn{4}{|c|}{ POLYGON DESCRIPTORS } & \multicolumn{3}{|c|}{ TERRAIN DATA } & \multicolumn{4}{|c|}{ SPECTRAL DATA } & \multicolumn{8}{|c|}{ SPECTRAL CLASSES } \\
\hline \multirow{2}{*}{$\begin{array}{l}\text { Polygon } \\
\text { No. }\end{array}$} & \multirow{2}{*}{$\begin{array}{l}\text { Physio- } \\
\text { graphic } \\
\text { Unit* }\end{array}$} & \multirow{2}{*}{$\begin{array}{c}\text { Total } \\
\text { Area } \\
\text { (acres) }\end{array}$} & \multirow{2}{*}{$\begin{array}{c}\text { Precipi- } \\
\text { tation } \\
\text { Zone } \\
\text { (1nches) }\end{array}$} & \multirow{2}{*}{$\begin{array}{c}\text { Mean } \\
\text { Slope } \\
\%\end{array}$} & \multirow{2}{*}{$\begin{array}{l}\text { Dom. } \\
\text { Aspect }\end{array}$} & \multirow{2}{*}{$\begin{array}{l}\text { Mean } \\
\text { Elev. } \\
\text { (feet) }\end{array}$} & \multicolumn{2}{|c|}{ Brightness } & \multicolumn{2}{|c|}{ Greenness } & \multicolumn{2}{|c|}{ Dominant } & \multicolumn{2}{|c|}{ Secondary } & \multicolumn{4}{|c|}{ No. Polygons } \\
\hline & & & & & & & $\frac{\text { Mean }}{\text { Mean }}$ & SD & Mean & SD & Class & $\begin{array}{c}\text { Area } \\
\%\end{array}$ & Ciass & $\underset{\%}{\text { Area }}$ & $\begin{array}{c}1 \\
\text { Acre }\end{array}$ & $\begin{array}{l}2-30 \\
\text { Acres }\end{array}$ & $\begin{array}{l}31-60 \\
\text { Acres }\end{array}$ & $\begin{array}{c}>60 \\
\text { Acres }\end{array}$ \\
\hline 258 & $211 \mathrm{~B}$ & 379 & $16-20$ & 12 & East & 6812 & 25 & 4 & 23 & 3 & 5 & 40 & 3 & 26 & $\mathbf{0}$ & 4 & 2 & 2 \\
\hline 290 & $209 \mathrm{C}$ & 247 & $16-20$ & 25 & South & 7025 & 27 & 3 & 25 & 2 & 5 & 46 & 3 & 25 & $\mathbf{0}$ & 1 & 1 & 2 \\
\hline 310 & $225 \mathrm{C}$ & 185 & $16-20$ & 23 & South & 7307 & 25 & 4 & 23 & 3 & 5 & 55 & 3 & 2.1 & 1 & 3 & 1 & 1 \\
\hline 346 & $222 \mathrm{C}$ & 96 & $16-20$ & 23 & North & 7118 & 26 & 4 & 24 & 3 & 3 & 50 & 5 & 22 & 0 & 5 & 1 & 0 \\
\hline 365 & $209 \mathrm{C}$ & 122 & $16-20$ & 25 & East & 7191 & 26 & 4 & 25 & 2 & 5 & 46 & 3 & 23 & 2 & 4 & 1 & 0 \\
\hline
\end{tabular}

*See Table 1. 


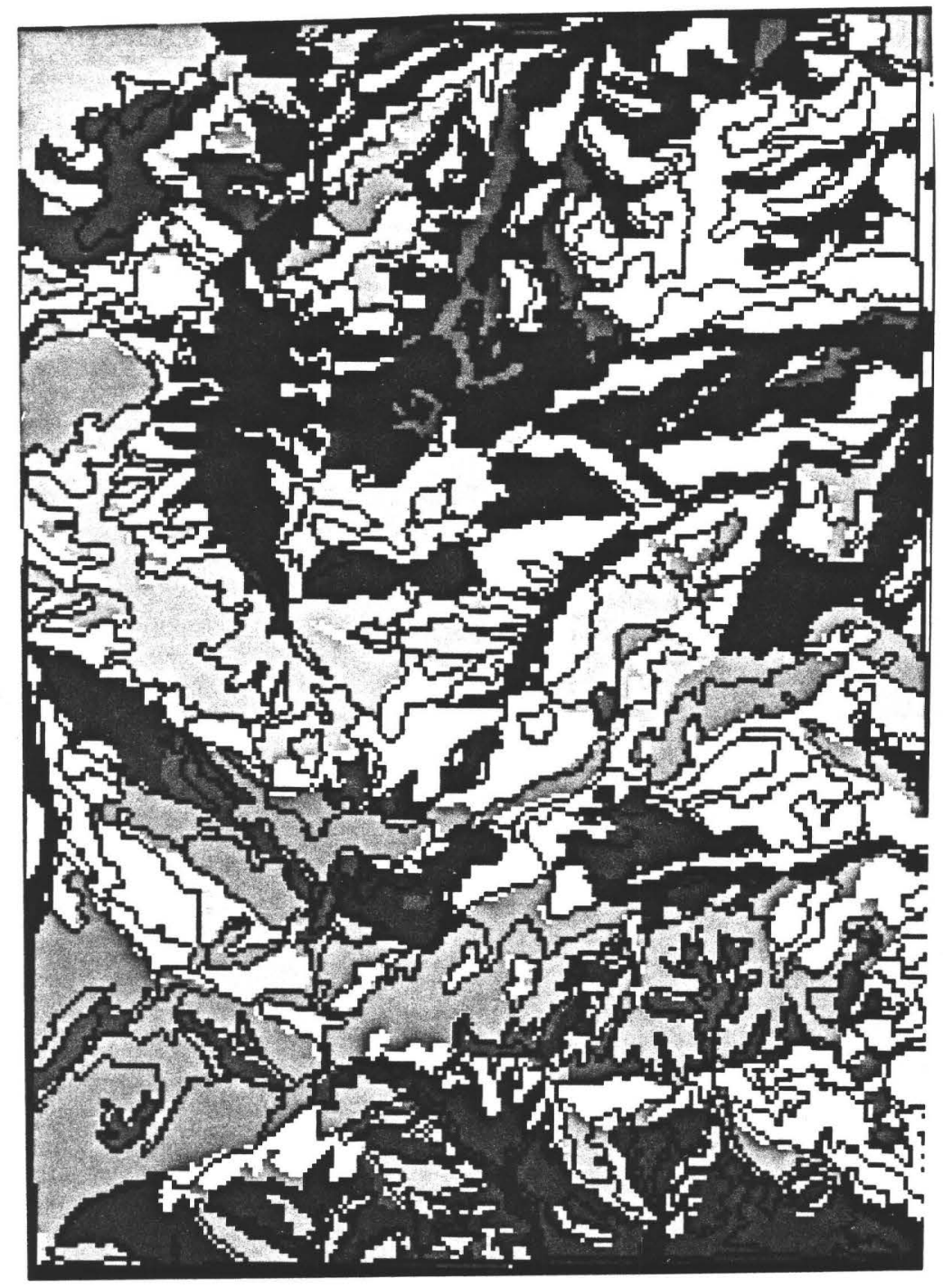

Figure 7.--Physiographic map (black lines) for the Soapy Dale Peak quadrangle placed over an order-three soil survey (colors), where different colors represent different soil mapping units and the black lines delineate different physiographic units. 
overlaid onto an existing order-three soil survey map, that had been generated by conventional soil survey methods. This overlay provides a qualitative comparison between the two maps. It was noticed that there are more lines on the physiographic map than on the soil survey map. In many instances lines that were present on the physiographic map but not on the soil survey map were due to slope differences that were evident in the terrain information.

\section{CONCLUSIONS}

Physiographic and spectral maps produced from digital terrain and Landsat multispectral scanner data identify slope interval categories and delineate units that relate to soils and range sites. When the two products were used in the field with the associated tabular summaries, they were found to be useful when delineating and labeling soil taxonomic units.

It is important to keep in mind the interpretation steps that the resource scientist has to take at the various levels of building the data base and during the mapping process. These steps are essential in the production of physiographic maps, where all the factors of soil formation as well as the genesis of the soils should be taken into consideration.

Preliminary field evaluations suggest that the use of physiographic maps and related data as discussed in this report could improve the quality and reduce the costs of making order-three soil surveys commonly used in rangeland management. 


\section{REFERENCES}

1. Doyle, F. J., 1978, Digital terrain mode1s: An overview: Photogrammetric Engineering and Remote Sensing, v. 44, no. 12, p. 1481-1485.

2. Di Paolo, W. D., and Hall, L. B., 1982, Landsat data for soils investigations on federal lands, in Johannsen, $\mathrm{C}_{.}$. J., and Sanders, J. L., eds., Remote Sensing for Resource Management: Ankeny, Iowa, Soil Conservation Society of America, p. 201-216.

3. Haas, R. H., Horvath, E. H., and Miller, W. A., 1983, Landsat applications for soil-vegetation inventory mapping; project final report, EROS Data Center, U.S. Geological Survey, Sioux Falls, South Dakota, 200 p.

4. Horvath, E. H., Post, D. F., Lucas, W. M., and Weismiller, R. A. (1980), Use of Landsat digital data to assist in mapping soils on Arizona rangelands, in International Symposium on Machine Processing of Remotely Sensed Data, 6th, West Lafayette, Indiana, 1980. Proceedings: West Lafayette, Laboratory for Applications of Remote Sensing, p. 235-240.

5. Jenny, H., 1941, Factors of soil formation: New York, McGraw Hill, 281 p.

6. Krebs, P. V., 1982, Multiresource inventory mapping of Alaska's wildlands: A cost-effective application of remote sensing, in Johannsen, C. J., and Sanders, J. L., eds., Remote Sensing for Resource Management: Ankeny, Iowa, Soil Conservation Society of America, p. 81-90.

7. Miller, W. A., Bonner, W. J. Rohde, W. G. and Schwartz, L. P., 1980, Digital Landsat and terrain data applied to an arid land resource inventory in Arid Land Resource Inventories: Developing Cost-Efficient Methods, La Paz, Mexico, 1980, Proceedings: U.S. Department of Agriculture, U.S. Forest Service, General Technical Report W0-28, p. 589-591.

8. Soil Survey Staff, 1975, Soil Taxonomy: A basic system of soil classification for making and interpreting soil surveys: Soil conservation Service, U.S. Department of Agricultre, Agriculture Handbook No. 436, 754 p.

9. Swain, P. H., and Davis, S. M., eds., 1978, Remote Sensing: The quantitative approach: New York, McGraw-Hill, 396 p.

10. Westin, F. C., 1982, Soil and land resource inventory using Landsat data, in Johannsen, C. J., and Sanders, J. L. eds., Remote Sensing for Natural Resource Management: Ankeny, Iowa, Soil Conservation Society of America, p. 243-252.

11. Young, W. H., and Isbe11, D. M., 1978, Production mapping with orthophoto digital terrain models: Photogrammetric Engineering and Remote Sensing, v. 44, no. 12, p. 1521-1536. 